IZA DP No. 4668

Land Rights Insecurity and Temporary Migration in Rural China

Maëlys de la Rupelle

Deng Quheng

Li Shi

Thomas Vendryes

December 2009 


\title{
Land Rights Insecurity and Temporary Migration in Rural China
}

\author{
Maëlys de la Rupelle
}

Paris School of Economics

Deng Quheng

Chinese Academy of Social Sciences

\author{
Li Shi \\ Beijing Normal University \\ and IZA
}

Thomas Vendryes

Paris School of Economics

\section{Discussion Paper No. 4668 \\ December 2009}

\author{
IZA \\ P.O. Box 7240 \\ 53072 Bonn \\ Germany \\ Phone: +49-228-3894-0 \\ Fax: +49-228-3894-180 \\ E-mail: iza@iza.org
}

Any opinions expressed here are those of the author(s) and not those of IZA. Research published in this series may include views on policy, but the institute itself takes no institutional policy positions.

The Institute for the Study of Labor (IZA) in Bonn is a local and virtual international research center and a place of communication between science, politics and business. IZA is an independent nonprofit organization supported by Deutsche Post Foundation. The center is associated with the University of Bonn and offers a stimulating research environment through its international network, workshops and conferences, data service, project support, research visits and doctoral program. IZA engages in (i) original and internationally competitive research in all fields of labor economics, (ii) development of policy concepts, and (iii) dissemination of research results and concepts to the interested public.

IZA Discussion Papers often represent preliminary work and are circulated to encourage discussion. Citation of such a paper should account for its provisional character. A revised version may be available directly from the author. 
IZA Discussion Paper No. 4668

December 2009

\section{ABSTRACT}

\section{Land Rights Insecurity and Temporary Migration in Rural China*}

Like most other developing countries, China experiences huge migration outflows from rural areas. Their most striking characteristic is a high geographical and temporal mobility. Rural migrants keep going back and forth between origin villages and destination areas. In this paper, we show that this temporary feature of migration can be linked to land rights insecurity. As village land ownership remains collective and as land use rights can be periodically reallocated, individual out-migration can result in deprivation of those rights. Moreover, the intensity of this insecurity varies according to the village-level management of land and the contractual status of land plots. We use these variations to identify the effect of land rights insecurity on migration behavior. Empirical results based on representative 2002 rural data demonstrate substantial impact.

JEL Classification: $\quad$ C34, J61, 015, P32, Q15

Keywords: migration, land rights insecurity, China, semiparametric censored regression models

Corresponding author:

Li Shi

Beijing Normal University

19 Xinjiekouwai Street

100875 Beijing

China

E-mail: lishi@bnu.edu.cn

\footnotetext{
*We would like to thank Marc Gurgand, Loren Brandt, Martin Fournier, Sandra Poncet, Anne-Sophie Robilliard, Chris Udry, Sylvie Lambert, Abla Safir, Sylvie Démurger, Martin Ravallion, Zhong Yuan, Terry Sicular and participants in various seminars and conferences for helpful comments.
} 


\section{Introduction}

According to the National Bureau of Statistics (NBS), the Chinese rural workforce amounted to 478.52 million people at the end of 2006 (see NBS (2006)). Of these, 131.81 million were migrant workers (nongmingong). Out-migration thus affects more than a quarter of the Chinese rural labor force. The individual characteristics, origins and destinations of Chinese rural migrants, as well as the impact of migration on Chinese urbanization and industrialization, have been well documented and analyzed.

Besides its numerical importance, another striking feature of this rural migrant population is its temporal and geographical mobility. For example, according to the results of a survey carried on in 2005 by the State Council Research Bureau on rural migrants (see State Council Research Bureau (2006)), only 8.13\% of the interviewed migrants declared that they planned a long term stay at their migration destination. The overwhelming majority of this population is therefore mobile, and indeed, rural migrants have been referred to, both in the Chinese media and in academic and political circles, as the "floating population" (liudong renkou). This extreme mobility of migrants can have important consequences for Chinese economic development. For example, in recent years, numerous developed coastal provinces have faced sudden "migrant worker shortages" (nongmin huang), jeopardizing production in labor-intensive, export-oriented industries.

This temporary pattern of rural out-migration does not fit the famous baseline migration models of Lewis (1954) and Harris and Todaro (1970). It is not specific to China, and the temporary migration phenomenon has already given birth to a wide literature in economics. The reasons invoked are: changes in the income differentials between origin and destination areas due for example to agricultural seasonality (Knight and Song (2003)), exogenous shocks on the legal and/or professional situations of migrants (Galor and Stark (1990)), psychological costs of migration, especially family ties (Djajic and Milbourne (1988)), a process of geographical job searching (Bhattacharya (1990)), and, finally, the desire of rural households to spread risks among sectors and localities (Stark 
and Levhari (1982), Stark and Bloom (1985)). However, on the empirical side, studies on the reasons of temporary migration remain scarce.

In this paper, we aim to show that this temporary feature of migration can also be linked to land rights insecurity. More specifically, our hypothesis is that land rights insecurity hinders migration, as the land use rights of out-migrating people can be seized during their absence. When exposed to a higher degree of insecurity, rural workers must migrate less, or for shorter periods. We thus focus on the link between the migration decisions of rural people and maybe the most important element of their rural environment: land.

This issue of land rights insecurity in developing countries has already been the subject of numerous empirical studies, focusing on productive investment (Goldstein and Udry (2008) for Ghana, Jacoby, Li, and Rozelle (2002) for China, Gautam, Dercon, and Ali (2007) for Ethiopia, to name just some of the most interesting articles), or labor allocation (Field (2007) for Peru, Lohmar (1999) and Shi (2004) in the case of China).

All these works face a common problem: how to identify the impact of land rights insecurity on individual behaviors? Some rely on instruments (such as Shi (2004)) while others use institutional variations in the definition of land rights (such as Goldstein and Udry (2008), Jacoby, Li, and Rozelle (2002) or Field (2007)). In this paper, we opt for a methodology close to this second solution. We use land rights heterogeneity across household plots in a model with village fixed effects to capture the impact of village land rights manipulation on out-migration. This strategy allows us to solve causality and endogeneity issues entailed by land arrangements at the village level. Indeed, village land management may respond to village migration history, or to village characteristics that affect migration as well. Yet, household exposure to village-level risk of land manipulation varies according to the type of plot tenure. While the type of tenure alone may raise endogeneity concerns, its interaction with village-level insecurity does not, once village fixed effects are taken into account. We are therefore able to identify the impact of land rights insecurity on migration behavior. Empirically, this approach is made possible by the width and the quality of the Chinese Household Income Project (CHIP) household 
survey, which gives detailed individual-level and village-level information on almost 9 200 rural Chinese households distributed in 961 villages all over China. Using Honoré (1992)'s semi-parametric identically censored least squares estimator, we actually find that the interaction between our indicator of village-level insecurity and a measure of the exposure of household plots to administrative seizure has a significant impact on rural households migration decisions: land rights insecurity does constrain migration behaviors and shortens out-migration durations for Chinese rural workers.

The plan of the paper is as follows. First, we delineate the migration phenomenon in contemporary China, and describe the main characteristics of land institutions. Second, we design a simple theoretical framework in order to formally establish the link between idiosyncratic land rights insecurity and migration decisions. This leads to our third section, namely empirical results.

\section{Migration and Land Rights in China}

The purpose of this first section is to provide a general picture of the temporary dimension of the migration phenomenon in China, and to see how it can be linked with the land rights insecurity generated by the institutional context of Chinese rural land management.

\section{CHIP Survey Description}

The following figures are based on past studies as well as descriptive statistics drawn from our data. Throughout this article, we rely on the Chinese Household Income Project (CHIP) cross-section survey conducted by the Chinese Academy of Social Sciences (CASS) in 2003. This was carried out during the 2003 Spring Festival, and investigated the situation of rural households during the preceding year. This survey has four main advantages. First, the set of questions was quite comprehensive, and deals with a large number of aspects of the lives of rural households. Second, the survey sample is 
very wide: 37969 people, from 9200 households distributed across 961 villages, ${ }^{1}$ were interviewed. The sample was chosen according to NBS data in order to be representative of the whole Chinese population. And for dimensions like age structure, gender ratio, or household composition, the survey results do indeed appear to be extremely similar to national statistics. Third, it was conducted during the Spring Festival, a time of traditional familial gathering. Consequently, a lot of migrants had returned to their hometown for the occasion and were present. Fourth, this individual and household level survey is complemented by extensive data on village level characteristics.

\section{Migration Definition and Sample Representativeness}

Migration is defined in relation to two criteria: work place, and work duration. For the purpose of this study, especially focused on the temporal dimension of migration, we define as a migrant in 2002 any individual who declared he worked out of his usual place of residence, whatever the duration of his out-migration. The only restriction we put on this definition is that the place of migrant work must not only be out of the individual's home village (cun) and township (xiang), but also out of the individual's home county $\left(x i a n^{2}\right)$, in order to rule out commuters and keep only genuine migrants.

Table 1 displays the distribution of the CHIP survey labor force according to the workers' primary work place. Using our definition of migration and according to the survey results, $15,4 \%^{3}$ of rural workers migrated in 2002, yielding an estimated national population of 93 million rural migrants. This fits remarkably well with official national statistics for 2002, of 94 millions rural migrants (Huang and Pieke (2003)), although our definition of migration differs from the NBS one ${ }^{4}$. These results give some evidence of

\footnotetext{
${ }^{1} 22$ provinces are sampled: (listed from East to West, and from North to South) Jilin, Liaoning, Beijing, Hebei, Shandong, Jiangsu, Zhejiang, Guangdong, Shanxi, Henan, Anhui, Hubei, Jiangxi, Hunan, Shaanxi, Chongqing, Guizhou, Guangxi, Xinjiang, Gansu, Sichuan, Yunnan. The survey covers 37969 individuals of 9200 households, in 961 villages distributed over 122 counties in these 22 provinces.

${ }^{2}$ There are four formal levels in the Chinese administrative structure, which, ranking from highest to lowest, are: province, prefecture, county and township. Villages are informal organizational levels below the township.

${ }^{3}$ We include as migrants in our definition workers declaring migrant work as a secondary occupation, which explains why the $15.4 \%$ figure is higher than the one computed from the fourth and fifth lines of table 1.

${ }^{4}$ The Chinese National Bureau of Statistics defines a migrant worker as an individual who has left
} 
the sample representativeness.

\section{TABLE 1 HERE}

Moreover, the characteristics of rural migrants in the 2002 CHIP survey are similar to those found in previous studies. As shown in table 2, compared to other rural people, migrants are younger, more educated, and more likely to be male and single. Migrant workers are less likely to be married, and less likely to be the head of household. Moreover, they are mainly long distance migrants, as a majority of them cross provincial borders. These results are very similar to the descriptive statistics given in other studies on Chinese rural migrants (see for example the aforementioned Huang and Pieke (2003), the reference works of Yao Zhaohui, Zhao (1999b) and Zhao (1999a), or the study of Li and Zanhiser (2002) on the 1995 CHIP survey).

\section{TABLE 2 HERE}

\subsection{Rural Migrations in China}

The diversity of the individual situations of rural migrant workers, often at the fringes of legality, as well as their high temporal and geographical mobility, challenges statistical tools. However, existing studies converge to a commonly accepted estimate of the growth in size of this population from around 2 million in the mid-1980s to about 94 million in 2002 (Huang and Pieke (2003)), and over 131 million by 2006 (State Council Research Bureau (2006)). That would mean that in China, at the beginning of the $21^{\text {st }}$ century, one worker out of six is a rural migrant.

The related economic literature, on the micro side, has focused mainly on the specific characteristics of migrant people, holding the classical Todarian point of view that labor income differentials were the main motive for migrations (Todaro (1969) and Harris and Todaro (1970)). Moreover, on the macro side, much of the political and social debate about Chinese internal migrations seems to be based on the implicit assumption that the underlying forces behind this phenomenon are comparable to the ones that caused rural depopulation in industrializing Europe and in most developing countries during the his registered place of residence in order to work, for at least 6 months in a given year. 
last two centuries. Rural out-migration flows are thus seen, in a Lewisian way (Lewis (1954)), as the shift of the agricultural "surplus labor" to the modern sectors, fueling capital accumulation, industrialization and urbanization.

However, a striking feature of rural migration flows in China does not fit the classical Lewisian-Todarian framework: their temporary nature. Indeed, it appears that most rural migrants come back to their home rural area, after some years spent working on urban informal labor markets, as noted, for example, by Murphy (2002). Out-migration thus seems to be a step in the life-cycle scheme of rural people. This impression is further confirmed by what has been called, in recent years, the "40 years phenomenon" (sishi sui xianxiang): in cities, virtually all rural migrant workers are under 40 years old. "Return migration" (huiliu) flows have also begun to draw attention. For example, as mentioned in the introduction, among the rural migrants surveyed for the Chinese rural migrant workers survey research report (State Council Research Bureau (2006)), only $8.13 \%$ declared that they planned a long term stay at the destination city, whereas $39.07 \%$ intend to go back to their hometown as soon as they have accumulated enough savings. In our data, about $75 \%$ of the rural migrants are less than 35 years old, that is, in the first part of their working life. All these points are consistent with the view that out-migration characterizes the first part of a rural individual's working life.

Moreover, during this migration stage of their lives, rural migrants keep on moving back and forth between home villages and destination areas (see Cook and Maurer-Fazio (1999)). For example, in the 2002 CHIP sample, only $5 \%$ of the migrants did not return to their home villages in 2002, and $60 \%$ of them spent less than 9 months outside their home counties. The distribution of the rural migrants according to the duration of their out-migration in 2002, plotted in figure 1, clearly reflects this temporary feature of rural migrations.

\section{FIGURE 1 HERE}

The rural migrant population of China thus displays a striking temporal characteristic: out-migration constitutes a transitory stage in a rural individual life pattern, and is a phenomenon of repeated moves between home and destination areas, rather than 
a more or less permanent settling. This paper deals with this second aspect of migration temporality. Many factors are likely to play a role in rural individuals' decisions regarding migration, and especially out-migration duration. Our hypothesis here is that land rights insecurity hinders out-migration, and especially shortens migration duration, because the longer people out-migrate, the more likely they are to be deprived of their land use rights.

\subsection{Land Rights Insecurity in China}

The purpose of this section is twofold. The first aim is to establish that there is land rights insecurity in China. The second is to present the variation in the intensity of this insecurity, across and within villages, that will eventually be used for the econometric investigation.

\section{The Hukou System and the Rural-Urban Divide}

Since the 1950s, Chinese people have been recorded in the "Household Registration System" or hukou framework. In the 1960s and 1970s, Chinese individuals' places of residence and work were strictly defined through this institution. ${ }^{5}$ Although the controls on mobility have been loosened over the last two decades, the very existence of this hukou system still constrains the moves of rural people, mainly because, as Solinger (1999) synthetically states, "civil/social rights and prerogatives, such as the right to subsistence, education, dwelling, employment, and medical care are denied to migrants in the cities". Rural migrants thus remain second-class citizens in urban areas, and though the hukou rural/urban divide is clearly less hermetic since the beginning of the reform era, it still firmly hinders rural migrants from settling permanently in cities. Symmetrically, this institution guarantees, for a rural hukou holder, the access to a piece of land. This land holding cannot be sold, and roughly substitutes for the social services and public goods rural people cannot access.

\footnotetext{
${ }^{5} \mathrm{~A}$ comprehensive depiction of the hukou system and its evolution can be found in: Cheng and Selden (1994). Evolutions of this system in the 1980s and 1990s are related in: Chan and Li (1999). The most recent overviews of this institution can be found in Wang (2004) and Chan and Buckingham (2008).
} 
This point is important for our study, for the hukou system constrains out-migrating rural people to eventually come back to their home villages, and establishes an institutional link between rural workers and agricultural land.

\section{The "Household Responsibility System" and Land Rights Insecurity}

The decollectivization of the rural economy and agricultural production, initiated in China at the end of the 1970s, has only been partial. At the beginning of the 1980s, the rural People's Communes were dismantled, ${ }^{6}$ but property rights on land have remained in the hands of village collective authorities. Rural households have only been conceded land use rights, intended to be implemented through a well-defined contractual framework, the "Household Responsibility System" (jiating lianchan chengbao zeren zhidu), but contracts, and especially the length of contracts, have not been respected by collective authorities. They have kept the habit of periodically reallocating land among their fellow villagers. This situation creates manifest uncertainty for rural households about the durability of their land tenure. This land rights insecurity and the correlative possible abuses from administrative authorities regularly give birth to outbursts of farmers' anger, which sometimes receive media coverage. It also attracts interest from political and academic circles, because of the consequences it may have for the investment decisions of Chinese rural households (Jacoby, Li, and Rozelle (2002)) and labor allocation (Lohmar (1999), Shi (2004)).

The common problem faced by all studies on land right insecurity and its consequences is that insecurity cannot be easily measured, and is potentially endogenous to the outcome of interest. Solutions include the estimation of "hazards of expropriation" for given plots (Jacoby, Li, and Rozelle (2002)), the use of instruments (Shi (2004) instruments village-level land rights insecurity with centrally imposed land re-contracting), or the use of various dimensions of variation in the intensity of land rights insecurity faced by individuals (as Goldstein and Udry (2008) did in the case of Ghana, using in-

\footnotetext{
${ }^{6}$ A general description of the "Household Responsibility System" can be found in Krusekopf (2002) and in Brandt, Huang, Li, and Scott (2002).
} 
dividuals' positions in the political hierarchy with regard to specific plots). The method we use here is close to this last solution. To identify the impact of land rights insecurity on migration duration, we rely on the interaction of two dimensions of variation of insecurity: the across-village variation, depending on differences in each village's collective management of land, and within-village, across-plot variation, depending on the different contractual status of land plots. These two dimensions of variation are presented in the next section.

\section{Dimensions of Land Rights Insecurity}

Collective Management of Land The "Household Responsibility System" framework was intended to be homogeneous throughout mainland China. However, its actual implementation by village authorities has taken very diverse forms. Despite the existence of land contracts, administrative redistributions have persisted, but their frequency and their criteria have differed considerably from one village to another, as Kung and Liu (1997) or Liu, Carter, and Yao (1998), for example, have documented. The involvement of village authorities in the actual management and allocation of agricultural land is extremely variable. In some villages, farmers' land use rights have effectively been enforced and protected, leading to a situation where land use rights are "quasi-private" (see Kung (2002)). In other places, collective land is periodically redistributed. This redistribution can take different forms, of varying extent, from the use of collective "flexible land" or "reserve fields" (jidong tian) to small scale reallocation (xiao tiaozheng) and village-wide land redistribution (da tiaozheng).

Decisions on land reallocation can be taken either at the administrative or at the natural village level (an administrative village gathers several natural villages). According to the 2002 CHIP survey data, reallocations are usually decided at the natural village level. Only one fifth of the reallocations were decided at the administrative village level. Land management policies thus generally respond to micro level decisions. The characteristics of village leaders and local interactions between villagers and their leaders play a key role in land rights determination, as Rozelle and Li (1998) stressed. 
Despite central state regulations to limit administrative land reallocation, $40 \%$ of the villages surveyed in 2002 had conducted at least one land reallocation since 1998. In some of them, adjustments even occurred almost every single year. In $23 \%$ of the villages, authorities retained some collective "reserve fields" in 2002.

The first dimension of variation in land rights insecurity is thus a village-level one, as the definition and stability of individual land use rights vary from one village to another, according to local political choices regarding agricultural land management and actual implementation of the "Household Responsibility System".

In this study, the variable we use to indicate the village-level dimension of insecurity is whether the village has retained some land in 2002 for adjustment (jidong tian, which is often translated as "reserve field" or "flexible land"). The existence of "flexible land" in 2002 means that there is room for land reallocation: land has been taken that can be redistributed. It thus indicates administrative land transfers at the village level. Moreover, it appears that these "reserve fields" have often been used by collective authorities in order to manipulate farmers and eventually increase levies, a practice that has been condemned by the Ministry of Agriculture since 1995 (see Cheng and Tsang (1996)). If a village retained "flexible land" in 2002, it thus indicates that there is village-level insecurity regarding land allocation.

Contractual Status of Plots In the framework of the "Household Responsibility System", different kinds of contracts on land are defined. Five major tenure types are officially sanctioned by the national government, each of them embodying a different set of rights and duties: ${ }^{7}$ private plot (ziliu di), grain ration land (kouliang tian), contract land (chengbao tian), responsibility land (zeren tian) and reclaimed land (kaihuang di). Each tenure type encompasses a different set of rights and obligations for rural households, and guarantees a different level of security.

Historically, the distinction between grain ration land and responsibility land appeared during the 1980s, when the institutional arrangement known as the "two fields

\footnotetext{
${ }^{7}$ For a precise and comprehensive account of different types of tenure in China, see the aforementioned article of Brandt, Huang, Li, and Scott (2002).
} 
system" (liang tian zhi) was experimented. First set up at the end of the 1980s in some counties of the Shandong povince, among which the most famous is Pingdu, this system progressively spread over China during the 1990s. Cheng and Tsang (1996) summarize this system as follows: "Under this scheme, some parts of the land are to be evenly distributed among the rural households as kouliang tian (land for the production of grain for self-consumption) with permanent tenancy rights. The remaining land is to be leased as shangpin tian (commodity land) or zeren tian (responsibility land) to grain-growing specialists by open bidding. Agricultural taxation and obligations to fulfill the state procurement quota are applied to the latter only". As is generally the case in rural China, official regulations and recommendations have not been directly and homogeneously implemented, and there have been local variations in the actual definition of the bundles of rights attached to grain-ration land and to responsibility land. Nevertheless, the founding principle has remained: kouliang tian is intended to enable farmers "to retain some land to secure their food supply" (Cheng and Tsang (1996)), whereas zeren tian is meant to be used to produce for the market and for the authorities, through quotas and taxes. Grain ration land plots are thus more secure than responsibility land, that is to say grain ration land is less likely to be seized and reallocated in case of out-migration because it is precisely designed to act as a "safety net" for farmers.

To simplify the analysis, we will divide households' land holdings into two general contractual types: grain ration and responsibility land. Private plots being qualitatively comparable and quantitatively marginal compared to grain ration land, we will include them under the label "grain ration land". For similar reasons, the label "responsibility land" covers responsibility land, contract land and reclaimed land.

Our hypothesis is that when land rights are jeopardized at the village level, rural individuals facing a lower insecurity on their land holdings should be more likely to migrate than those with higher insecurity. To formally express this hypothesis, we design, in the next section, a simple model, to analyze the allocation of a rural agent labor between migration and agriculture, taking into account these two dimensions of land rights insecurity. 


\section{A Model of Temporary Migration with Insecure Land Rights}

We design here a very simple model of a rural household migration decision in a context of land rights insecurity. This illustrative model carries out two objectives. First, it enables to determine under which conditions land rights insecurity has an impact on migration decisions. Second, it formally introduces and justifies the empirical method we use to identify the impact of land rights insecurity on migration decisions, that is, the interaction between village-level land rights insecurity and the contractual structure of rural households' land tenure.

\section{$2.1 \quad$ Framework}

In this study, decisions are studied at the household level rather than the individual level. In fact, land plots are, in most of the cases, contractually granted to farmers households, and not to individuals. In any case, the 2002 CHIP questionnaire collected information on land at the household level. This also implies that we will consider that labor allocation decisions, and especially migration decisions, are taken at the household level. We will thus adopt an unitary conception of the household ${ }^{8}$. Even when individuals out-migrate, income pooling still occurs at the household level. A unitary view of Chinese rural households should thus not be too misleading.

\section{Household Endowments and Life Cycle}

A household life-cycle is divided into two periods. During the first, the household can decide to allocate some work time to migration, while in the second one it definitively settles down in the rural area. That constraint makes the model much more tractable

\footnotetext{
${ }^{8}$ Without denying that household decisions are the results of intra-household negotiation and bargaining, the unitary model seems to be quite relevant in the Chinese case, especially for the matter of migration decisions. As rural migrant workers are usually relegated to a secondary status in Chinese cities, and are denied access to urban social services, or even formal urban housing, they are constrained not to consume in urban areas, and to save and remit a huge part of their earnings to their rural household.
} 
without modifying the central result, and seems to be realistic. Indeed, as mentioned earlier, for most Chinese rural individuals and households, migration appears to be a first step, a first period of their life-cycle, before a definitive return and settling in rural areas.

The household is endowed with a quantity of labor $L$, constant over time. It is also endowed with an overall quantity of land $T_{1}$, which includes both its "grain ration land", $T_{G 1}$, and its "responsibility land", $T_{R 1}$. As explained earlier, the first kind of land cannot be lost, reallocated or transferred by collective authorities, while the second kind can be seized and transferred to other agents from period to period, if a reallocation occurs. We will denote by $s$ the share of "grain ration land" in the first period land endowment. We thus have $T_{G 1}=s T_{1}$ and $T_{R 1}=(1-s) T_{1}$.

To sum up, the initial endowment of a rural household is given by the set $\left(L, T_{G 1}, T_{R 1}\right)$, or, alternatively, $\left(L, T_{1}, s\right)$.

\section{First Period}

During the first period, the household allocates labor between the rural activity and migration. We assume that the rural activity involves the use of land and labor, and that the agent acts as a private entrepreneur. So the rural activity yields an income $F\left(T_{1},(1-m) L\right)$, and migration provides a total income $m L w$, where $m$ is the share of the household working time spent migrating, $1-m$ being the time devoted to the rural activity. $F(T,(1-m) L)$ is the household rural production function. We assume that $F($.$) is increasing and concave in both arguments. { }^{9}$. Finally, $w$ is the migrant wage. The agent's first period income is then a function of $m$ :

$$
W_{1}(m)=F\left(T_{1},(1-m) L\right)+m L w
$$

\footnotetext{
${ }^{9}$ Note that we take "grain ration land" and "responsibility land" as perfect substitutes in production. However, even if they differ in quality or other productive characteristics, that does not modify our main result.
} 


\section{Second Period}

During the second period, the household cannot migrate; its whole income is thus generated through the rural activity, which yields an income $F\left(T_{2}, L\right)$. Moreover, its first period responsibility land, $T_{R 1}$, may have been reallocated between the two periods. We thus have $T_{2}=T_{G 2}+T_{R 2}$, with $T_{G 2}=T_{G 1}=s T_{1}$, because grain ration land is secure, and $T_{R 2}=f(.) T_{R 1}=f().(1-s) T_{1}$, where the function $f($.$) captures the changes in$ responsibility land through redistribution.

From the above, it follows that $f($.$) will depend on time spent migrating in the first$ period, $(1-m) L$, the function $f($.$) being decreasing in m$, and on collective management of land, $Z$. As mentioned earlier, villages' policies on land vary, and land rights are more secure in some places than in others. For this study, and for the reasons given earlier, we will use the fact that village authorities have retained some "flexible land" as an indication that there is administrative involvement in land management, and thus land rights insecurity for households.

Thus, second period income is:

$$
W_{2}(m)=F\left(s T_{1}+f(Z,(1-m) L)(1-s) T_{1}, L\right)
$$

\section{Migration Decision}

The rural household decides the optimal allocation of its labor during the first period so as to maximize its intertemporal income ${ }^{10}$ (which equals its intertemporal utility, with a discount rate taken as equal to one).

\footnotetext{
${ }^{10}$ To simplify our analysis, we have not introduced savings. Doing so and maximizing household's intertemporal consumption gives similar results.
} 
Using (1) and (2), the maximization program of the agent is:

$$
\begin{aligned}
\max _{m} W= & F\left(T_{1},(1-m) L\right)+m L w \\
& +F\left([s+(1-s) f(Z,(1-m) L)] T_{1}, L\right) \\
\text { s.t. } & 1 \geq m \geq 0
\end{aligned}
$$

\subsection{Land Rights Insecurity and Migration}

\section{Optimal Labor Allocation and Optimal Migration Duration}

The agent's optimization program yields two corner solutions, $m=0$ and $m=1$. When $m=0$, no time is devoted to migration. It is more profitable for the household to spend all its first-period working time in the rural area, because the marginal productivity of rural labor is higher than the marginal income of migration, that is the urban informal sector wage. When $m=1$, all working time is spent out-migrating. It is more profitable for the household to spend all its first-period working time migrating, because the marginal productivity of its rural labor is always lower than the marginal income of migration.

The interior solution, such that $0<m^{*}<1$, satisfies the condition:

$$
\begin{aligned}
& -F_{2}\left(T_{1},\left(1-m^{*}\right) L\right)+w \\
& -(1-s) T_{1} f_{2}\left(Z,\left(1-m^{*}\right) L\right) F_{1}\left(\left[s+(1-s) f\left(Z,\left(1-m^{*}\right) L\right)\right] T_{1}, L\right)=0
\end{aligned}
$$

where $F_{1}, F_{2}$ and $f_{2}$ are the partial derivatives of $F($.$) and f($.$) with respect to their$ first and second argument.

In the case where land rights are secure, the time spent out-migrating during the first period does not affect the quantity of land available in the second period, formally $f_{2}=0$, and so the optimal migration duration simply equates the marginal income of the rural activity, $F_{2}$, and the marginal income earned on the urban labor market, $w$. 
If land use rights are not secure, that generates a new migration cost. This cost is formally equal to $f_{2} T_{R 1} F_{1}$, that is to say it is equal to the marginal productivity of land in the second period, $F_{1}$, multiplied by the marginal gain or loss of "responsibility land" quantity due to out-migration, $f_{2}(1-s) T_{1}$. Quite intuitively, this cost is the marginal income loss caused by the loss of land due to out-migration.

\section{Land Rights Insecurity and Optimal Migration Duration}

Equation (4) implicitly defines the optimal migration decisions $m^{*}$ as a function of the quantity of land and of the productivity in the rural activity, $T_{1}, T_{2}$ and $F_{1}, F_{2}$, of the migrant wage, $w$, and of land rights insecurity, through $s$, the structure of the land endowment according to the contractual status of plots, and through the possible loss of responsibility land due to out-migration, $f_{2}\left(Z,\left(1-m^{*}\right) L\right)(1-s) T_{1}$.

There are thus two dimensions of land rights insecurity that bear consequences for migration decisions, the first one at the household level, the second at the village level. Our econometric estimation will be based on these two dimensions.

At the village-level, we will use the fact that village authorities retained some "reserve fields" in 2002 as an indication of their actual involvement in land management and plot distribution among households. We will denote by $R$ the existence $(R=1)$ or not $(R=0)$ of these "reserve fields". This dummy thus indicates whether there is insecurity at the village level.

At the household level, we use $s$, the share of grain ration land in a household land holding. The higher $s$, the more secure is the household land, as "Grain ration land" quantity does not vary, whereas "Responsibility land" quantity can change due to village leaders' decisions, and this change will depend on the migration decision. $s$ can thus be seen as indicating the exposure of a household land endowment to land rights insecurity.

Formally, we can express these hypotheses as follows:

If $R=0, T_{G 2}=T_{G 1}=s T_{1}$ and $T_{R 2}=T_{R 1}=(1-s) T_{1}$ (i.e., $f($.$) is constant),$

If $R=1, T_{G 2}=T_{G 1}=s T_{1}, T_{R 2}=f(Z,(1-m) L) T_{R 1}=f(Z,(1-m) L)(1-s) T_{1}$

$(i e, f($.$) is not a constant, and depends on the migration duration). Moreover, we add$ 
the assumption that $f_{2}>0$ : the time spent at home positively affects the quantity of "responsibility land" available in the second period.

From the expression (4) and the above-mentioned assumptions, we get the following results: ${ }^{11}$

$$
\begin{aligned}
& \frac{\partial m^{*}}{\partial s}=0 \text { if } R=0(\text { ie land rights are secure }) . \\
& \left.\frac{\partial m^{*}}{\partial s}>0 \text { if } R=1 \text { (ie land rights are jeopardized }\right) .
\end{aligned}
$$

If land rights are secure and not jeopardized, the contractual structure of the agent's land endowment, between "responsibility" plots and "grain ration" plots, should have no effect on migration decisions. This result is quite intuitive, for the main difference between the two kinds of plots is their exposure to insecurity and administrative redistribution. On the contrary, if land plots can be reallocated among villagers, the share of "grain ration land" in an agent's land holding should have a positive effect on the share of working time she can spend migrating, because when land rights are jeopardized, only "responsibility land" is likely to shrink. An agent with a larger share of "grain ration land" in her land holding is thus less exposed to land rights insecurity. She can afford to migrate more, as she is less constrained by the need to be in her village asserting her rights and defending her interests. This interaction between land rights insecurity at the village level and the contractual structure of households' land plots is the key element of our econometric estimation.

\section{Empirical Results}

Our model has led to a set of implications about the link between land rights insecurity and migration duration. In this section, we first describe our identification strategy and then present our results.

\footnotetext{
${ }^{11}$ See Appendix A for the proof.
} 


\subsection{Econometric Specification}

To investigate the impact of land rights insecurity on migration decision, we have to deal with two main econometric issues: endogeneity and censoring. This subsection aims to show how our strategy, implemented within a semiparametric censored regression framework, will solve both of them.

\section{Identification Strategy}

The main factor of land rights insecurity is village land insecurity among households. Yet, looking at the impact of land manipulation on villagers' migration decisions raises an endogeneity problem. Indeed, village land manipulation and villagers' migration decision can both be caused by village-level unobserved characteristics. Besides, it is likely that reverse causality takes place between land management and migration, for if a land seizure can have an impact on migration decisions, it is also possible that villagers' migration behaviors have an effect on village's management of land. In our empirical inquiry, we solve this endogeneity problem by using the interaction between land manipulation and the contractual structure of household land. Alone, the type of tenure of household land holdings might not be exogenous. For instance, there could be some systematic bias in village policies towards grain ration land. But despite being subject to heterogenous policies between villages, grain ration land will always be considered as more secure than other types of land at the household level. Moreover, the influence of grain ration land on households' migration decisions should be the same in all the villages if none of them have reserve fields, once household characteristics and village effects have been taken into account. This provides us with a key hypothesis in our identification strategy. To express this formally, let us consider the following reduced form, that gives the share of household working time devoted to migration, $m$, according to our model.

$$
m(T, s, R, X, Z)=\alpha T+\lambda X+\gamma R+\beta_{R} s \times R+\beta s+\epsilon
$$


$X$ represents observed household characteristics. $R$ is the dummy indicating the fact that village authorities retained "reserve fields" in 2002. $T$ is the amount of land used by the household, while $s$ gives the share of "grain ration land" in total land plots. $s \times R$, the interaction between $R$ and $s$, is the term of interest. Finally, $\epsilon$ is the error term.

As mentioned before, we have $E(\epsilon \mid s, R) \neq 0$. Our key assumption is that the error term is separable between $s$ and $v$, with $v$ indexing the villages.

$$
E(\epsilon \mid s, v)=\epsilon_{s}+\epsilon_{v}
$$

That is to say, two households with similar $X$ and $T$ but different shares of grain ration land, $s$ and $s^{\prime}$, will have the same difference in $\epsilon$ on both types of village, either with $R=1$ or $R=0$. Hypothesis (7) implies:

$$
\forall\left(s, s^{\prime}\right), E\left(\epsilon \mid s^{\prime}, R=1\right)-E(\epsilon \mid s, R=1)=E\left(\epsilon \mid s^{\prime}, R=0\right)-E(\epsilon \mid s, R=0)
$$

Our hypothesis, somewhat similar to the parallel trend hypothesis in a difference-indifference strategy, as (8) shows, allows us to exploit the interaction term $s \times R$. After replacing the error term by its two components, the expectation of migration duration becomes :

$$
E(m \mid v, T, s, X, R)=\alpha T+\lambda X+\gamma R+\beta_{R} s \times R+\beta s+\epsilon_{s}+\epsilon_{v}
$$

Conditioning on the village fixed effects, $\epsilon_{v}$, the exogeneity of other independent variables $\left(T\right.$ and $X$ ) is not a concern, and $\beta_{R}$ becomes our unique indicator of migration response to land insecurity. Indeed, it is clear that nothing can be said about the impact of each dimension of land insecurity, taken alone.

Obviously, $\beta$ is not identified. $\frac{\partial m}{\partial s}=0$ if $R=0$ will not be tested.

It is clear as well that we cannot disentangle the land seizure effect, $\gamma$, from the village fixed effects, $\epsilon_{v}$ : the latter will include the former. $\frac{\partial m}{\partial R}<0$ cannot be tested either. 
Yet, we can test one important implication of the model : $\beta_{R}>0$. Provided sufficient variation in $s$ within villages of both $R=1$ and $R=0$ types, $\beta_{R}$ is identified, as implied from (7).

The structure of land endowment according to types of land tenure thus allows us to identify the effect of land rights insecurity on households' migration decisions. The interaction of the occurrence of land retention with the proportion of grain ration land in household land holdings provides us with a way of overcoming the land manipulation endogeneity problem.

\section{Censored regression model with fixed effects}

The second problem we have to face is the censoring of our dependent variable, $m$, the share of household working time spent migrating. Obviously, $m$, the share we observe in our data, cannot be less than 0 or greater than 1 .

The upper censoring is not a concern. Indeed, the share of migrant work is equal to one for only twenty-two households. Rural households, given their size (they often contain several generations), and given the constraints they face, are very unlikely to have all their members working all year as migrants. Whether or not we exclude them has little effect on our results. We therefore choose not to deal with the upper censoring. Our main preoccupation is the left censoring, affecting nearly $70 \%$ of the households.

To take into account the censoring, we implement a semi-parametric estimator for censored model with fixed effects described by Honoré (1992), the Identically Censored Least Squares estimator (ICLS). ${ }^{12}$ To do so, we need a narrow set of hypotheses. We assume the error terms to be independent, identically and continuously distributed conditional on the independent variables and on the village fixed effect. Having no parametric hypotheses on the error terms is of particular interest as we have to deal with left-censoring. We use the downhill simplex method as optimization routine. ${ }^{13}$

\footnotetext{
${ }^{12}$ Honoré (1992) proposes two estimators, depending on whether the objective function is based on least absolute deviation or on least squares. We choose the latter, more appropriate when the censoring level of the dependent variable is high.

${ }^{13}$ The implementation mainly relies on the programs written by Bo Honoré for GAUSS. Four optimization routines are provided: the downhill simplex method, Powell's method, the conjugate gradient
} 


\subsection{Empirical Results}

\section{First Insights}

As explained above, our empirical investigation uses the interaction between village land insecurity and the contractual status of household land holdings to identify the impact of land rights insecurity on migration duration.

Confidence in the actual impact of this interaction can be derived first from the following graphs. In figures 2 and 3, we plot the distribution of households including at least one migrant worker, according to the share of their working time devoted to migration. We plot separately this distribution for the households who have some grain ration land, and for those who do not. Figure 2 shows migration patterns for these two kinds of households in 2002 for villages where no "flexible land" was retained that year, whereas figure 3 displays the same distributions, but for villages where some "flexible land" was retained by village authorities.

\section{FIGURE 2 HERE}

\section{FIGURE 3 HERE}

From the comparison between these two figures, it appears that while the owning of some grain ration land does not seem to have a strong impact on households' migration decisions in villages where no "flexible land" is retained (figure 2), it shifts the share of working time devoted to migration to the right when some "flexible land" is actually retained by village authorities (figure 3 ). Grain ration land thus seems to allow a household to migrate more when land rights are insecure in a village, that is to say, grain ration land seems to act as a protection when land rights are jeopardized.

We now turn to the formal econometric analysis of the effect on migration decisions of this interaction between village uncertainty and the contractual status of plots.

method of Polak and Ribiere, and the Broyden-Fletcher-Goldfarb-Shanno (BFGS) method. We use the downhill simplex method because it is better at minimizing the objective function. 


\section{Variables}

The dependent variable According to our theoretical framework, we consider households' working time, and we focus on the share of this working time allocated to migration. More specifically, the dependent variable $m$ is, for a given household, the time spent working out of the county, divided by the time spent working, for all the workers of that household. In our sample, the time allotted to migration by households is, on average, $10 \%$.

Land variables The key land variables are the total area of land used by the household, the share of grain ration land in total land, and the interaction between the share of grain ration land and the village-level land insecurity variable, namely whether or not the village retained some "flexible land" in 2002.

A household's land endowment is $9.7 \mathrm{mu}$ on average, with grain ration land accounting for $39 \%$ of that. As mentioned earlier, $23 \%$ of sampled villages retained some "flexible land" in 2002.

Households characteristics In our theoretical framework, we have identified important household-level characteristics. Among them, the migration wage and the household's ability to work cannot appear directly in the reduced form. The variables we use are the reduced form determinants: years of education of the head of household, the proportion of men among working members, mean age and mean age squared.

Additional Household Controls As control variables, we add three households variables in some specifications: the share of dependent members (young and old) in the household, a dummy associated with households from ethnic minorities, and a wealth indicator built from the durable goods possessed by household.

Tables 7 in the appendix presents descriptive statistics for all variables. 


\section{Results}

Baseline regression results are presented in table 3.

\section{TABLE 3 HERE}

As we can see, the coefficient of the interaction between land rights insecurity and grain ration land is found to be positive, amounts to 0.19 , and is significant at the $2 \%$ level. This result strongly confirms our main hypothesis: we actually get $\beta_{R}>0$. The coefficient of the interaction term shows that land rights insecurity acts as a hindrance on migration. When land is manipulated by village authorities, a household whose plots are less exposed to reallocation because of its status can afford a longer migration duration. This also reveals that land endowments are still an important variable in household migration decisions.

What does the magnitude of the coefficient mean? Since our dependent variable is censored, we can obtain information on both the latent variable and the observed variable. The coefficient 0.19 gives information on the impact of the interaction term on the desired migration duration, $m^{\star}$. Let us consider a fictive average household, whose working time amounts to 745 days. If flexible land is retained at the village level, an additional percentage point of secure grain ration land in total land endowment will increase the desired share of working time devoted to migration by 0.19 percentage point. This amounts to $0.0019 * 745=1.4$ additional days of migration.

To get the magnitude of the marginal effect on the actual migration duration, additional calculation is required. As Honoré (2008) stated, the average marginal effect on the dependent variable $m$ is obtained by multiplying the coefficient by the probability that $m$ is not censored ${ }^{14}$. Migration duration is uncensored with a probability of 0.29 . Therefore, if land rights are insecure, an additional percentage point of grain ration land share will increase migration duration by $0.29 * 0.0019 * 745=0.4$ day. Let us consider two households, whose grain ration land shares differ by a standard deviation. If land rights are jeopardized, the migration differential between them would be 15 days. This

\footnotetext{
${ }^{14}$ Provided that the censoring points do not change while considering a change in the independent variable of interest. This condition is satisfied here.
} 
is a significant variation, for an average household allocates $10.2 \%$ of its working time to migration, which amounts to 76 days.

Among the other variables, total land area has a slight negative impact on migration duration. This result is quite intuitive, since as Zhao (1999b) stated, land scarcity is a considerable push factor. However, unlike Zhao (1999b), we are not concerned here with the binary decision of migration, as we focus on migration duration. More land naturally increases the productivity of agricultural labor, and thus reduces both the probability to migrate and the time devoted to migration.

Regarding the other variables, the results obtained are consistent with our expectations. The share of grain ration land, alone, has no significant effect on migration duration. The share of dependent members is found to have quite a strong and negative impact on migration duration (-0.23), significant at the $1 \%$ level. Education and age variables are also significant, at the five and ten percent level respectively. The higher the education level of the head of household, the shorter the migration duration. This confirms numerous studies showing that local off-farm jobs are scarce and that the most highly-educated people will have more opportunities to work in local off-farm jobs. Local off-farm work is usually their first best choice (see Guang and Zheng (2005)). The younger the household is on average, the larger the share of its working time devoted to migration. The dummy associated with ethnic minority is non significant. One explanation may be that ethnical diversity within village may be small, and the effect of ethnic origins may be entangled in village fixed effects.

Wealth indicators prove to be non significant, except for the dummy associated with the wealthiest households, significant at the $1 \%$ level. The wealthiest households migrate less. This is consistent with previous studies, pointing out that the wealthiest households have neither the need nor the desire to migrate. Among the selected controls, the variables related to wealth are of particular concern. On the one hand, one could argue that wealth indicators are endogenous. The purchase of durable goods can be a result of migration history. On the other hand, one could be surprised by their low significance, and fear that they fail to capture differences between households' ability to pay migration 
costs or to undertake productive activities. Among the three dummies included in the regression, the last one (motorbike or car ownership) is the only significant one. Yet it is desirable to control for all the variables explaining the different choices faced by the household. To answer our first concern, we run the same regression without wealth indicators, and find no significant alteration of our coefficient of interest. Results are displayed in the same table, under the label ICLS (2). Once wealth indicators are omitted, the coefficient of our variable of interest is equal to 0.18 , and remains significant at the $5 \%$ level. As for our second concern, to check whether our variable properly captures wealth impacts on migration, we try using different wealth controls. We run the same regressions, with and without dummies for durable goods, adding the estimated value of self-owned house (columns (3) and (4)). Results are not altered. The coefficient of this variable is positive. In the absence of dummies for durable goods, it is significant at the $10 \%$ level. The richer the household is, the longer the migration duration will be, the very upper fringe remaining the exception.

Still, these wealth indicators may fail to account properly for the capital that a household owns and can use in its farming activity. As agricultural production plays a crucial role in our model, we run additional regressions with different controls, the results of which are shown in table 4 . One relevant variable is the value of household fixed productive assets. The fixed assets related to agricultural production encompass draught animals, farm tools, and machinery. We run a similar regression by adding the value of these fixed productive assets. Their effect on migration decisions is strongly significant, and has, as expected, a negative sign. To better understand what type of fixed productive assets are of importance, we add each item separately. As column (6), (7) and (8) of table 4 show, the effect of these assets is largely driven by farm tools and machinery. Draught animals alone have no significant impact; they probably do not help differentiate between different households in a village.

TABLE 4 HERE

The estimated value of household fixed productive assets captures wealth as well as capital used in agricultural production. In this case, the dummies related to durable 
goods may not be sufficient to capture household wealth. We add to the regression a variable that captures wealth in a continuous way, the estimated value of self-owned house. Results are shown in table 5, column (9). Productive assets still have a significant and negative impact, and the significance and value of the coefficient of the interaction between grain ration land and the retention of flexible land increases, whereas the land variable becomes less significant. The value of productive fixed assets is indeed likely to be collinear with the size of land. Keeping in mind the possibility of endogeneity, we remain cautious in interpreting such variables. However, we see from these additional regressions that results are quite robust when the indicators used for wealth are omitted or enriched with additional types of wealth controls.

TABLE 5 HERE

\subsection{Robustness checks}

In this section, we present two sets of additional regressions in order to assess the robustness of our results.

\section{Social status}

In the theoretical framework we have designed, local off-farm work is not an option considered by the household. This simplification relies on the assumption that the tradeoff between local off-farm work and migration is of less importance than the trade-off between migration and agriculture. The household which has access to local off-farm work will take advantage of it, and the remaining working time will then be subject to a choice between agriculture and migration. Migration is mostly seen as a secondbest option, as Guang and Zheng (2005) observed. Therefore, the choice of migration duration should not be affected very much by the duration of local off-farm work. Yet, the total working time of each household includes off-farm work as well as migration and agriculture. And even if only a limited number of households in our sample are involved in both off-farm work and migration, local off-farm work is an alternative to rural households, that could call into question our modeling. The dependent variable 
being a ratio, if our hypothesis is not correct, then variations in household working time devoted to local off-farm work would affect the migration working time. In this case, the addition of variables that are of essential importance in explaining access to local off-farm work would change our results substantially. An interesting control to add is a variable accounting for the household social status. In the context of a rural economy lacking off-farm job opportunities, social status is of strong importance in facilitating access to off-farm jobs. Communist Party membership, in China, helps to identify households more likely to get access to interesting local off-farm positions. Whereas its impact on migration is not clear and appears to be insignificant, the CCP membership variable is likely to play a key role in explaining access to local off-farm jobs. As far as migration is concerned, even if social status does play a role, it is likely that its impact depends mainly on existing networks and on the migration history of the village, and most of the effects at play should therefore be captured by the village fixed effects.

We therefore run a regression adding a dummy indicating whether the head of household belongs to the Chinese Communist Party. If off-farm work substantially affected household working time allotted to migration duration, one would expect this variable to have a significant effect or to alter the coefficients obtained previously for other variables. In fact, the inclusion of this variable does not alter our results, as shown by the ICLS (10) regressions of table 5, and this variable is found to be non-significant. A comparison with the first regression (ICLS (1)) shows that the variables of interest have identical coefficients. The results are consistent with our analysis. We are not claiming, however, that social status has no impact on migration duration. It is possible that the social status has two offsetting effects, people with better connections being either rich enough not to need to migrate, or well enough connected to village leaders not to fear land seizure if they do out-migrate. Nevertheless, this regression makes us confident that the simplifications made in our theoretical framework are reasonable. The addition of a key variable impacting local off-farm working opportunities does not alter the coefficient of the variables of interest. Our conclusion is not jeopardized. 


\section{Off-farm work and migration}

Our main robustness check aims to assess the relevance of our identification strategy. In this paper, we have argued that rural migrants may be deprived of some of their land because they are away from their villages, and are thus not present to defend their rights. We have claimed that the interaction between the retention of collective "flexible land" by village authorities in 2002 and the proportion of grain ration land in a household's total land holdings enables to identify the impact of land insecurity on migration decisions.

However, it could be possible that the significant and positive impact of this interaction term on migration behaviors is not due to land rights insecurity issues, penalizing absent individuals, but that it is caused by other reasons, affecting the general trade-off between agricultural work and off-farm work, local or out of the village.

If that was the case, the interaction term would be correlated not only with migration, but, more generally, with off-farm work, local or not. It would thus be positively correlated, not only with migration behaviors, but also with local off-farm work. On the other hand, if the interaction term does identify the impact of land rights insecurity, then its impact on the time allocated to local off-farm work should be small, if not insignificant. After all, individuals working off-farm but locally can be present to assert their rights and defend their interests if their rights are jeopardized.

As a robustness check, to verify that this interaction term captures the effect of land rights insecurity, we run a regression almost identical to the preceding ones, except that we take as dependent variable not the ratio of the time spent migrating to total working time, but the ratio of local off-farm work to total working time. In our sample, on average, households spent $22 \%$ of their working time in local off-farm jobs. If the coefficient associated with the interaction term is negligible or insignificant, that would confirm that our previous results actually identify an impact of land rights insecurity on migration.

Results are presented in Table 6. Whatever the specification, the coefficient associated with the interaction is much lower than in the previous regression : 0.07. With a 
standard deviation of 0.05 , it is found to be non-significant. These regressions therefore strongly confirm our previous results.

\section{TABLE 6 HERE}

It is also interesting to note that local off-farm working time responds in a slightly different way to the different independent variables. The dummies associated with household durable goods are more significant. The dummies for two bicycles and for motorbike or car are both significant at the $1 \%$ level: wealth seems to matter more for access to local off-farm jobs than for migration opportunities. The social status variable is found to have a highly significant positive impact, with a coefficient of 0.08 . The strong impact of Communist Party membership on local off-farm opportunities confirms some of the interpretations proposed above.

\section{Conclusion}

In this paper, we investigate the effect of land rights insecurity on the migration decisions of rural people, and more specifically on migration duration. The underlying idea, formalized in a simple model, is that in a context where collective authorities can seize and reallocate land plots, the more time an individual spends out of her village, the more likely she is to lose at least some of her land. Future land holdings are thus endogenous as they depend on present migration duration. Moreover, land use rights insecurity in China is idiosyncratic, depending as it does on village-level management of collective land and on the contractual status of plots. The effect of out-migration duration on changes in land holdings is thus not the same for all rural people, and the consequent constraint on migration is more acute for some than for others.

The empirical results drawn from a 2002 CASS survey data using a semiparametric censored regression model strongly support these views. It appears that, when land use rights are jeopardized, migration behavior varies with the contractual structure of land holdings. When land is manipulated by village authorities, households having more secure grain ration land plots can afford to spend more time migrating. 
It is well known that land rights insecurity has a strong effect on rural households' investment decisions. We show here that land rights insecurity also influences households' labor allocation. Insecure and inalienable land rights act as a centripetal force, preventing rural people from moving out of agriculture and out of rural areas.

The results we obtained here also stress that the "floating" characteristic of rural migrants in China is not only due to the administrative constraints on definitive settling in urban areas, through the hukou registration system, but is also a consequence of the institutional arrangements in rural areas. If rural migrants do not settle in cities, but keep moving back and forth between home villages and destination areas, it is not only because cities push them back, but also because their home villages actually pull them back.

However, even if land rights insecurity is a manifest constraint on the labor allocation of rural households, one should not unilaterally conclude that Chinese institutional land arrangements should be merely removed, and land rights privatized.

Firstly, it is not clear that if land rights were privatized and controls on population moves loosened, rural people would take the individually and socially optimal decisions on their labor allocation. Actually, one of the main arguments of the Chinese State against freeing land and labor allocations is the fear of "blind migrations" (mangliu) by rural people to the cities.

Secondly, the effects of Chinese land arrangements are not limited solely to the dimension of rural labor allocation. It is possible that this constraint they impose on rural households is counterbalanced by advantages in other areas. Indeed it appears that Chinese farmers did not, at least in the end of the 1990s, generally seem to favor an evolution toward privatization, as James Kai-sing Kung and Liu Shouying (see Kung James (1995) and Kung and Liu (1997)) were the first to notice when they investigated Chinese farmers' preferences. It is thus possible that these drawbacks of the collective ownership of land are seen, in Chinese rural areas, as the price to pay for still under-studied gains from this institutional framework. For example, even if land use rights on particular plots are not guaranteed over time, the collective management of land secures an access 
to agricultural land for any rural individual. It could thus constitute an insurance device for Chinese rural people, who, generally speaking, bitterly lack all kinds of social security services. Our study results appear to back such an intuition, for the huge proportion of people who tend to cut short their stay in cities when a reallocation occurs proves how much they rely on the land. Even if land itself may not be sufficient to provide a living for a household, and even if farming households hope to find off-farm occupations, at home as well as in distant cities, it remains a protection when the future is uncertain.

\section{A Comparative statics: The effect of the share of grain- ration plots in total land endowment, $s$, on the optimal share of working time spent migrating, $m^{*}$, depending on village-level land rights insecurity, $R$.}

We want to prove that:

$$
\begin{aligned}
& \frac{\partial m^{*}}{\partial s}=0 \text { if } R=0 \text { (ie land rights are secure). } \\
& \frac{\partial m^{*}}{\partial s}>0 \text { if } R=1 \text { (ie land rights are insecure). }
\end{aligned}
$$

From equation (3), we know that the objective function of the household $C$ depends on the choice variable $m$ and the parameter $s$, with $(m, s) \in[0 ; 1]^{2}$ :

$$
C(m, s)=F\left(T_{1},(1-m) L\right)+m L w+F\left([s+(1-s) f(Z,(1-m) L)] T_{1}, L\right)
$$

When land rights are secure $(R=0)$, the quantity of land does not change from the first to the second period, $f()=$.1 , the objective function is simply:

$$
C(m, s)=F\left(T_{1},(1-m) L\right)+m L w+F\left(T_{1}, L\right)
$$


$C($.$) therefore does not depend on s$, and so, obviously, the optimal $m$ does not depend on $s$ either. We thus have our first result:

$$
\frac{\partial m^{*}}{\partial s}=0 \text { if } R=0
$$

When land rights are insecure $(R=1)$, the quantity of land does change from the first to the second period, and this evolution is captured by the function $f($.$) . We make$ the following assumptions on this function.

When $m>0, f($.$) is increasing in the share of working time spent in the rural$ area, or, alternatively, decreasing in $m$. Moreover, we assume that $f()<$.1 . Indeed, $f()>$.1 would mean that the household would actually gain more "responsibility land" during an administrative reallocation of plots. This is not likely to be the case, for outmigrating households are always a minority of a village population, and the only likely redistribution of land is from less frequently present people to more frequently present ones. There is no chance that a household with an out-migrating member could gain more land. So we can assume that $f()<$.1 if $m>0$.

When $m=0, f() \geq$.1 for the same reasons as expressed above: the only likely redistribution of land is from less frequently present people to more frequently present ones, and so households that do not migrate at all should gain, or at least not lose, "responsibility land".

To sum up, we assume that $f($.$) is continuously differentiable, increasing in the$ working time spent in the rural area (i.e., decreasing in $m$ ), and inferior to 1 when $m \in] 0 ; 1]$. However, $f($.$) displays a discontinuity for m=0$, and $f(L) \geq 1$.

When $m \in] 0 ; 1]$, we know that $m^{*}(s)=\arg \max _{m \in[0 ; 1[} C(m, s)$, where $C($.$) is contin-$ uously differentiable in $m$, and the cross partial derivative of $C(m, s)$ is:

$$
\begin{aligned}
& -T_{1} f_{2}(Z,(1-m) L)\left[-F_{1}\left([s+(1-s) f(Z,(1-m) L)] T_{1}, L\right)\right. \\
& \left.+(1-s) T_{1}(1-f(Z,(1-m) L)) F_{1}^{2}\left([s+(1-s) f(Z,(1-m) L)] T_{1}, L\right)\right]>0
\end{aligned}
$$

for $f_{2}>0, F_{1}>0,(1-s) T_{1} \geq 0, F_{1}^{2} \leq 0$, because of the decreasing returns of the rural 
activity, and finally $f()<$.1 .

$C(m, s)$ therefore has strictly increasing differences in $(m, s)$, and, by Topkis theorem ${ }^{15}$, we get our result:

$\frac{\partial m^{*}}{\partial s}>0$ if $R=1$ and for $m>0$.

To show that the previous property holds on the whole segment $[0 ; 1]$, that is, including the case $m=0$, we have to establish that $C$ has increasing differences even when $m$ is at its boundary 0 . We take two values of $m, 0$ and $\bar{m}>0$ and two values of $s, \bar{s}$ and $\underline{s}$, with $\bar{s}>\underline{s}$. We then have:

$$
\begin{aligned}
& (C(\bar{m}, \bar{s})-C(0, \bar{s}))-(C(\bar{m}, \underline{s})-C(0, \underline{s})) \\
= & F\left([\bar{s}+(1-\bar{s}) f(Z,(1-\bar{m}) L)] T_{1}, L\right)-F\left([\underline{s}+(1-\underline{s}) f(Z,(1-\bar{m}) L)] T_{1}, L\right) \\
+ & F\left([\underline{s}+(1-\underline{s}) f(Z, L)] T_{1}, L\right)-F\left([\bar{s}+(1-\bar{s}) f(Z, L)] T_{1}, L\right)
\end{aligned}
$$

Which is positive, for $\bar{s}>\underline{s}, f(V,(1-\bar{m}) L)<1 \leq f(V, L)$, and $F($.$) is increasing in$ both arguments. $C($.) thus has increasing differences for all $m \in[0 ; 1]$.

We then get our second result:

$$
\frac{\partial m^{*}}{\partial s}>0 \text { if } R=1
$$

\section{B Descriptive Statistics}

TABLE 7 HERE

\section{References}

Bhattacharya, G. (1990): "Migration Under Uncertainty About Quality of Locations," Journal of Economic Dynamics and Control, 14(3-4), 721-739.

Brandt, L., J. Huang, G. Li, and R. Scott (2002): "Land Rights in China: Facts, Fictions and Issues," The China Journal, 47, 67-97.

${ }^{15}$ See Topkis (1978). 
Chan, K. W., and W. Buckingham (2008): "Is China Abolishing the Hukou System?," The China Quarterly, 195, 582-606.

Chan, K. W., and Z. Li (1999): "The Hukou System and Rural-Urban Migration in China: Processes and Changes," The China Quarterly, 160, 818-855.

Cheng, T., and M. Selden (1994): "The Origins and Social Consequences of China's Hukou System," The China Quarterly, 139, 644-688.

Cheng, Y.-S., and S.-K. Tsang (1996): "Agricultural Land Reform in a Mixed System: The Chinese Experience of 1984-1994," China Information, X(3), 44-74.

Cook, S., And M. Maurer-Fazio (eds.) (1999): The Workers' State Meets the Market: Labour in China's Transition. Taylor \& Francis.

Djajic, S., And R. Milbourne (1988): "A General Equilibrium Model of GuestWorker Migration: The Source-Country Perspective," Journal of International Economics, 25(3-4), 335-351.

Field, E. (2007): "Entitled to Work: Urban Property Rights and Labor Supply in Peru," The Quarterly Journal of Economics, 122(4), 1561-1602.

Galor, O., and O. Stark (1990): "Migrants Savings, the Probability of Return Migration and Migrant's Performance," International Economic Review, 31(2), 463-467.

Gautam, M., S. Dercon, and D. A. Ali (2007): "Property Rights in a Very Poor Country: Tenure Insecurity and Investment in Ethiopia," Policy Research Working Paper Series 4363, The World Bank.

Goldstein, M., and C. Udry (2008): "The Profits of Power: Land Rights and Agricultural Investment in Ghana," Journal of Political Economy, 116(6), 981-1022.

Guang, L., And L. Zheng (2005): "Migration as the Second-best Option: Local Power and Off-farm Employment," The China Quaterly, 181, 22-45.

Harris, J. R., and M. P. Todaro (1970): "Migration, Unemployment and Development: A Two-Sector Analysis," The American Economic Review, 60(1), 126-142.

Honoré, B. E. (1992): "Trimmed LAD and Least Squares Estimation of Truncated and Censored Regression Models with Fixed Effects," Econometrica, 60(3), 533-65.

(2008): "On Marginal Effects in Semiparametric Censored Regression Models," Working paper series, Princeton University.

Huang, P., And F. N. Pieke (2003): "China Migration Country Study," presented at the Regional Conference on Migration, Development and Pro-Poor Policy Choices in Asia, Dhaka, Bangladesh. 
Jacoby, H. G., G. Li, and S. Rozelle (2002): "Hazards of Expropriation: Tenure Insecurity and Investment in Rural China," The American Economic Review, 92(5), $1420-1447$.

Knight, J., And L. Song (2003): "Chinese Peasant Choices: Farming, Rural Industry Or Migration," Oxford Development Studies, 31(2), 123-148.

Krusekopf, C. C. (2002): "Diversity in Land-Tenure Arrangements Under the Household Responsibility System in China," China Economic Review, 13(2-3), 297-312.

KunG, J. K.-S. (2002): "Choice of Land Tenure in China: The Case of a Country with Quasi-Private Property Rights," Economic Development and Cultural Change, 50(4), 793-817.

KunG, J. K.-S., And S. LiU (1997): "Farmers' Preferences Regarding Ownership and Land Tenure in Post-Mao China: Unexpected Evidence from Eight Counties," The China Journal, 38, 33-63.

Kung James, K. (1995): "Equal Entitlement versus Tenure Security under a Regime of Collective Property Rights: Peasants' Preference for Institutions in Post-reform Chinese Agriculture," Journal of Comparative Economics, 21(1), 82-111.

LEWIS, A. W. (1954): "Economic Development with Unlimited Supply of Labour," The Manchester School of Economic and Social Studies, 22, 131-191.

Li, H., And S. Zanhiser (2002): "The Determinants of Temporary Rural-to-Urban Migration in China," Urban Studies, 39(12), 2219-2235.

Liu, S., M. R. Carter, and Y. Yao (1998): "Dimensions and Diversity of Property Rights in Rural China: Dilemmas on the Road to Further Reform," World Development, 26(10), 1789-1806.

Lohmar, B. (1999): "Land Tenure Insecurity and Labor Allocation in Rural China," in American Agricultural Economics Association, 1999 Annual meeting, August 8-11, Nashville, TN.

Murphy, R. (2002): How Migrant Labor is Changing Rural China. Cambridge University Press.

NBS (2006): Communiques on the Main Data from the Second National Survey on Agriculture, Dierci quanguo nongye pucha zhuyao shuju gongbao. China Statistical Publishing House, These communiques are available (in Chinese) at the following address:

http://www.stats.gov.cn/tjgb/nypcgb/qgnypcgb/index.htm.

Rozelle, S., AND G. Li (1998): "Village Leaders and Land-Rights Formation in China," American Economic Review, 88(2), 433-38. 
SHI, X. (2004): "The Impact of Insecure Land Use Rights on Labor Migration: The Case of China.," CCER Economic Papers, 4(22), 1-24.

Solinger, D. J. (1999): "Citizenship Issues in China's Internal Migration: Comparisons with Germany and Japan," Political Science Quarterly, 114(3), 455-478.

Stark, O., and D. E. Bloom (1985): "The New Economics of Labor Migration," The American Economic Review, 75(2), 173-178, Papers and Proceedings of the NinetySeventh Annual Meeting of the American Economic Association.

Stark, O., and D. Levhari (1982): "On Migration and Risks in LDCs," Economic Development and Cultural Change, 31(1), 191-196.

State Council Research Bureau, t. (2006): Chinese Rural Migrant Workers Survey Research Report, Zhongguo Nongmingong Diaoyan Baogao. The main results have been summarized by the National Population and Family Planning Commission of China, and are available (in Chinese) at the following address:

http://www. chinapop.gov.cn/rkxx/rkxw/t20060417_58579.htm.

Todaro, M. (1969): "A Model of Labor Migration and Urban Unemployment in Less Developed Countries," The American Economic Review, 59, 138-148.

Topkis, D. M. (1978): "Minimizing a Submodular Function on a Lattice," Operation Research, 26(2), 305-321.

Wang, F.-L. (2004): "Reformed Migration Control and New Targeted People: China's Hukou System in the 2000s," The China Quarterly, 177, 115-132.

Zнао, Y. (1999a): "Labor Migration and Earnings Differences: The Case of Rural China," Economic Development and Cultural Change, 47(4), 767-82.

(1999b): "Leaving the Countryside: Rural-to-Urban Migration Decisions in China, 89, 2:281-286, May 1999.," American Economic Review, 89, 281-286. 


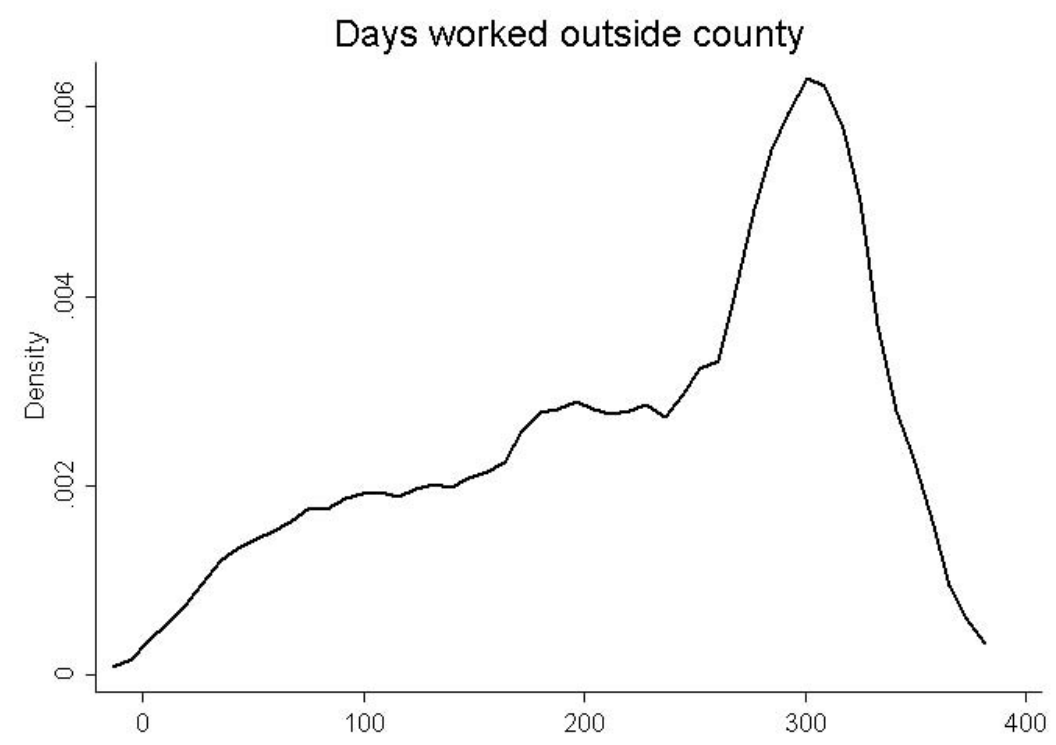

Figure 1: Migration days - density (Sample restricted to migrant individuals). 


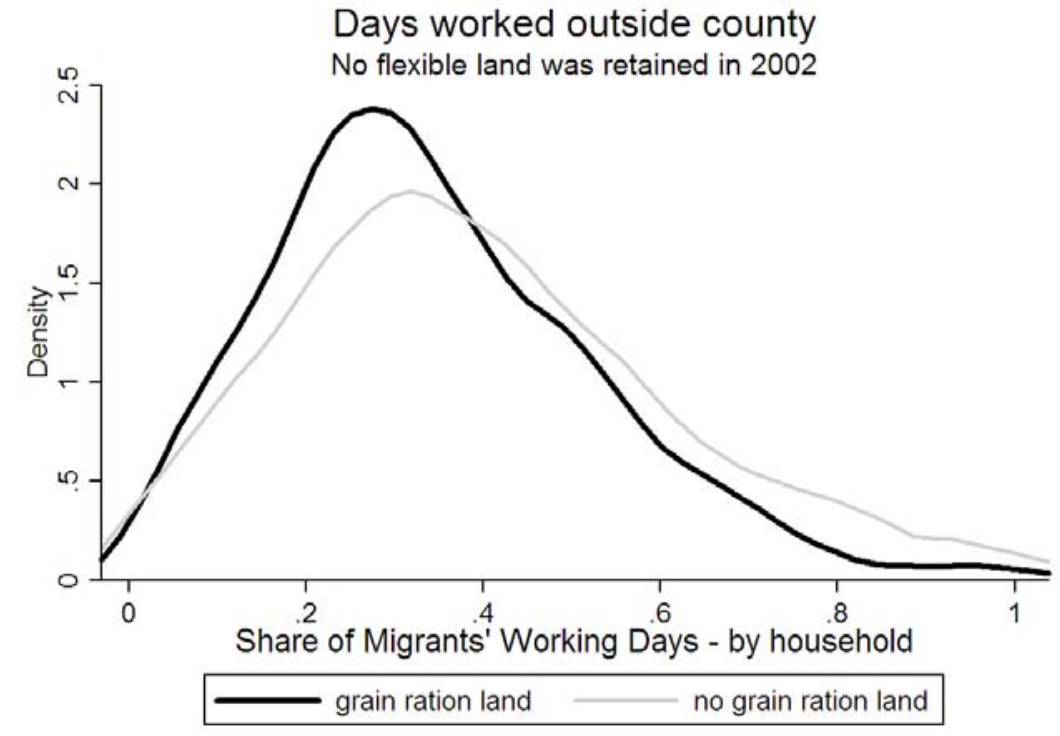

Figure 2: Share of household working time spent migrating depending on households' contractual status of land plots when no "flexible land" was retained

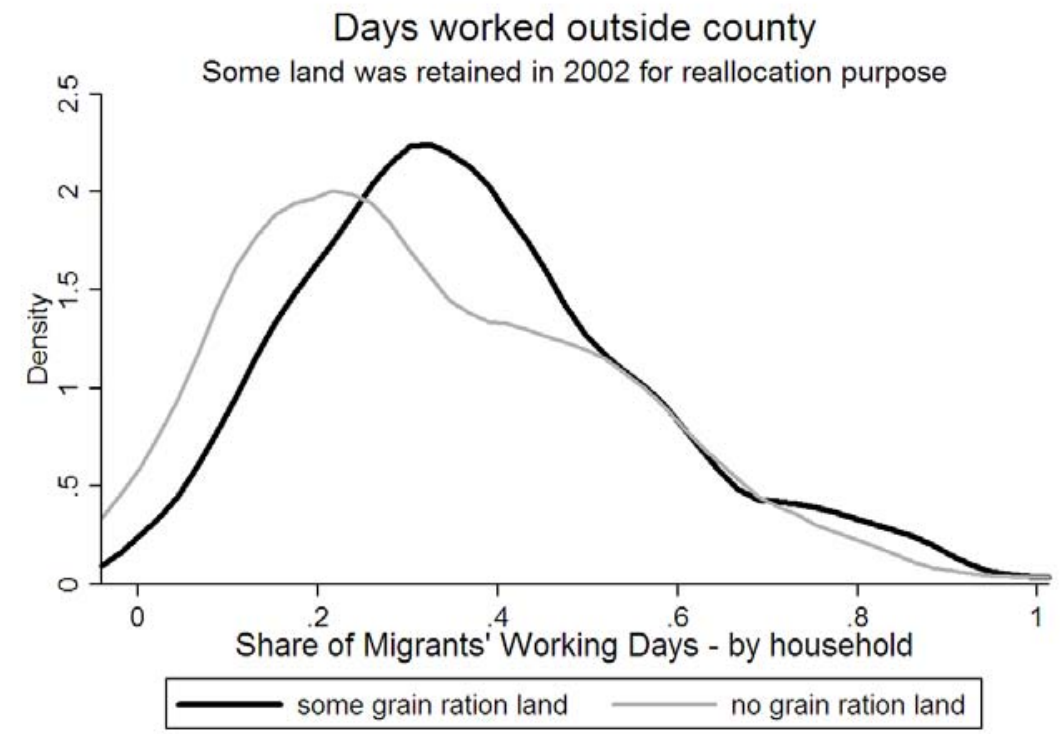

Figure 3: Share of household working time spent migrating depending on households' contractual status of land plots when some "flexible land" was retained 


\begin{tabular}{lc} 
Agricultural work (within village) & 52,68 \\
\hline Within village & 16,55 \\
\hline Outside village, within township & 10,31 \\
\hline Outside township, within county & 5,59 \\
\hline Outside county, within province & 6,78 \\
\hline Outside province & 8,10 \\
\hline & \\
Total & $100 \%$ \\
\hline \hline
\end{tabular}

Table 1: Primary work place

Table 2: Descriptive statistics on labor force

\begin{tabular}{lccc}
\hline \hline \multicolumn{1}{c}{ Variable } & Migrants & Non migrants & All workers \\
\hline Mean & & & \\
Age & 28,7 & 40,2 & 38,6 \\
Years of education & 8,7 & 7,4 & 7,6 \\
\hline Proportion (\%) & & & \\
Men & 66,6 & 52,8 & 54,8 \\
Married & 48,5 & 82,5 & 38,6 \\
Household's head & 23,9 & 38,6 & 36,5 \\
\hline Number of obs. & 3404 & 20425 & 23829 \\
\hline \hline
\end{tabular}


Table 3: Dependent variable: Ratio of migration duration to total working time (1)

\begin{tabular}{|c|c|c|c|c|}
\hline \multirow[b]{3}{*}{ Variables } & \multicolumn{4}{|c|}{ Identically Censored Least Squares Regressions } \\
\hline & ICLS (1) & ICLS (2) & ICLS (3) & ICLS (4) \\
\hline & $\begin{array}{l}\text { Coefficient } \\
\text { (Std. Err.) }\end{array}$ & $\begin{array}{l}\text { Coefficient } \\
\text { (Std. Err.) }\end{array}$ & $\begin{array}{l}\text { Coefficient } \\
\text { (Std. Err.) }\end{array}$ & $\begin{array}{l}\text { Coefficient } \\
\text { (Std. Err.) }\end{array}$ \\
\hline Total area of land & $\begin{array}{l}-0.003^{* *} \\
(0.0012)\end{array}$ & $\begin{array}{l}-0.003^{* * *} \\
(0.0011)\end{array}$ & $\begin{array}{l}-0.003^{* * *} \\
(0.0011)\end{array}$ & $\begin{array}{l}-0.003^{* * *} \\
(0.001)\end{array}$ \\
\hline Share of grain ration land & $\begin{array}{r}-0.04 \\
(0.038)\end{array}$ & $\begin{array}{r}-0.04 \\
(0.039)\end{array}$ & $\begin{array}{r}-0.04 \\
(0.039)\end{array}$ & $\begin{array}{r}-0.05 \\
(0.039)\end{array}$ \\
\hline $\begin{array}{l}\text { Flexible land retained in } 2002 \\
\times \text { Share of grain ration land }\end{array}$ & $\begin{array}{l}\mathbf{0 . 1 9}^{* *} \\
(0.075)\end{array}$ & $\begin{array}{c}\mathbf{0 . 1 8}^{* *} \\
(0.073)\end{array}$ & $\begin{array}{c}\mathbf{0 . 1 9}^{* *} \\
(0.073)\end{array}$ & $\begin{array}{l}\mathbf{0 . 1 9}^{* * *} \\
(0.074)\end{array}$ \\
\hline Share of dependent members & $\begin{array}{l}-0.23^{* * *} \\
(0.028)\end{array}$ & $\begin{array}{l}-0.23^{* * *} \\
(0.029)\end{array}$ & $\begin{array}{l}-0.23^{* * *} \\
(0.03)\end{array}$ & $\begin{array}{l}-0.22^{* * *} \\
(0.03)\end{array}$ \\
\hline Years of education of hh head & $\begin{array}{l}-0.005^{* *} \\
(0.0023)\end{array}$ & $\begin{array}{l}-0.005^{* *} \\
(0.0024)\end{array}$ & $\begin{array}{l}-0.005^{* *} \\
(0.0024)\end{array}$ & $\begin{array}{l}-0.005^{* *} \\
(0.0023)\end{array}$ \\
\hline Hh mean age & $\begin{array}{l}-0.03^{* * *} \\
(0.005)\end{array}$ & $\begin{array}{l}-0.03^{* * *} \\
(0.005)\end{array}$ & $\begin{array}{l}-0.03^{* * *} \\
(0.005)\end{array}$ & $\begin{array}{l}-0.03^{* * *} \\
(0.005)\end{array}$ \\
\hline Hh mean age squared & $\begin{array}{l}0.0002^{* * *} \\
(0.00006)\end{array}$ & $\begin{array}{l}0.0002^{* * *} \\
(0.00006)\end{array}$ & $\begin{array}{l}0.0002^{* * *} \\
(0.00006)\end{array}$ & $\begin{array}{l}0.0002^{* * *} \\
(0.00006)\end{array}$ \\
\hline Hh mean number of men & $\begin{array}{r}0.03 \\
(0.03)\end{array}$ & $\begin{array}{l}-0.02 \\
(0.03)\end{array}$ & $\begin{array}{r}0.02 \\
(0.03)\end{array}$ & $\begin{array}{r}0.02 \\
(0.03)\end{array}$ \\
\hline Ethnic minority & $\begin{array}{r}0.02 \\
(0.06)\end{array}$ & $\begin{array}{l}-0.02 \\
(0.06)\end{array}$ & $\begin{array}{l}-0.02 \\
(0.06)\end{array}$ & $\begin{array}{l}-0.02 \\
(0.06)\end{array}$ \\
\hline $\begin{array}{l}\text { Household durable goods } \\
\text { (ref: three or more bikes) } \\
\text { One bicycle }\end{array}$ & $\begin{array}{r}y e s \\
-0.05 \\
(0.029)\end{array}$ & no & no & $\begin{array}{c}\text { yes } \\
-0.05^{*} \\
(0.028)\end{array}$ \\
\hline Two bicycles & $\begin{array}{l}-0.01 \\
(0.02)\end{array}$ & & & $\begin{array}{r}-0.02 \\
(0.018)\end{array}$ \\
\hline Motorbike or car & $\begin{array}{l}-0.07^{* * *} \\
(0.02)\end{array}$ & & & $\begin{array}{l}-0.07^{* * *} \\
(0.02)\end{array}$ \\
\hline $\begin{array}{l}\text { Estimated value of } \\
\text { self-owned house }\end{array}$ & & & $\begin{array}{l}6.8 \mathrm{E}-7^{*} \\
(3.5 \mathrm{E}-7)\end{array}$ & $\begin{array}{l}8 \mathrm{E}-7^{* *} \\
(3.5 \mathrm{E}-7)\end{array}$ \\
\hline $\begin{array}{l}\chi^{2} \text { test for joint significance } \\
\text { Number of villages : } \\
\text { Number of households : }\end{array}$ & $\begin{array}{r}422 \\
(\mathrm{p}-\mathrm{val}=0 \%) \\
862 \\
8005\end{array}$ & $\begin{array}{r}393.7 \\
(\mathrm{p}-\mathrm{val}=0 \%) \\
862 \\
8005\end{array}$ & $\begin{array}{r}415 \\
(\mathrm{p}-\mathrm{val}=0 \%) \\
862 \\
8005\end{array}$ & $\begin{array}{r}441 \\
(\mathrm{p}-\mathrm{val}=0 \%) \\
862 \\
8005\end{array}$ \\
\hline
\end{tabular}

Significance levels: $\quad * 10 \% \quad * * 5 \% \quad * * * 1 \%$ 
Table 4: Dependent variable: Ratio of migration duration to total working time (2)

\begin{tabular}{|c|c|c|c|c|}
\hline \multirow[b]{3}{*}{ Variables } & \multicolumn{4}{|c|}{ Identically Censored Least Squares Regressions } \\
\hline & ICLS (5) & ICLS (6) & ICLS (7) & ICLS (8) \\
\hline & $\begin{array}{l}\text { Coefficient } \\
\text { (Std. Err.) }\end{array}$ & $\begin{array}{l}\text { Coefficient } \\
\text { (Std. Err.) }\end{array}$ & $\begin{array}{l}\text { Coefficient } \\
\text { (Std. Err.) }\end{array}$ & $\begin{array}{l}\text { Coefficient } \\
\text { (Std. Err.) }\end{array}$ \\
\hline Total area of land & $\begin{array}{l}-0.002^{* *} \\
(0.001)\end{array}$ & $\begin{array}{l}-0.003^{* *} \\
(0.0012)\end{array}$ & $\begin{array}{l}-0.003^{* * *} \\
(0.0011)\end{array}$ & $\begin{array}{l}-0.003^{* * *} \\
(0.0012)\end{array}$ \\
\hline Share of grain ration land & $\begin{array}{r}-0.04 \\
(0.038)\end{array}$ & $\begin{array}{r}-0.04 \\
(0.038)\end{array}$ & $\begin{array}{r}-0.04 \\
(0.039)\end{array}$ & $\begin{array}{r}-0.04 \\
(0.039)\end{array}$ \\
\hline $\begin{array}{l}\text { Flexible land retained in } 2002 \\
\times \text { Share of grain ration land }\end{array}$ & $\begin{array}{c}\mathbf{0 . 1 8} \\
(0.072)\end{array}$ & $\begin{array}{c}\mathbf{0 . 1 8} \\
(0.075)\end{array}$ & $\begin{array}{c}\mathbf{0 . 1 9}^{* *} \\
(0.074)\end{array}$ & $\begin{array}{l}\mathbf{0 . 1 9}^{* *} \\
(0.074)\end{array}$ \\
\hline Share of dependent members & $\begin{array}{l}-0.23^{* * *} \\
(0.03)\end{array}$ & $\begin{array}{l}-0.23^{* * *} \\
(0.03)\end{array}$ & $\begin{array}{l}-0.23^{* * *} \\
(0.03)\end{array}$ & $\begin{array}{l}-0.23^{* * *} \\
(0.029)\end{array}$ \\
\hline Years of education of hh head & $\begin{array}{l}-0.005^{* *} \\
(0.0023)\end{array}$ & $\begin{array}{l}-0.005^{* *} \\
(0.0023)\end{array}$ & $\begin{array}{l}-0.005^{* *} \\
(0.0023)\end{array}$ & $\begin{array}{l}-0.005^{* *} \\
(0.0023)\end{array}$ \\
\hline Hh mean age & $\begin{array}{l}-0.03^{* * *} \\
(0.005)\end{array}$ & $\begin{array}{l}-0.03^{* * *} \\
(0.005)\end{array}$ & $\begin{array}{l}-0.03^{* * *} \\
(0.005)\end{array}$ & $\begin{array}{l}-0.03^{* * *} \\
(0.005)\end{array}$ \\
\hline Hh mean age squared & $\begin{array}{l}0.0002^{* * *} \\
(0.00006)\end{array}$ & $\begin{array}{l}0.0002^{* * *} \\
(0.00006)\end{array}$ & $\begin{array}{l}0.0002^{* * *} \\
(0.00006)\end{array}$ & $\begin{array}{l}0.0002^{* * *} \\
(0.00006)\end{array}$ \\
\hline Hh mean number of men & $\begin{array}{r}0.03 \\
(0.03)\end{array}$ & $\begin{array}{r}0.03 \\
(0.03)\end{array}$ & $\begin{array}{l}-0.03 \\
(0.03)\end{array}$ & $\begin{array}{l}-0.02 \\
(0.03)\end{array}$ \\
\hline Ethnic minority & $\begin{array}{l}-0.02 \\
(0.06)\end{array}$ & $\begin{array}{l}-0.03 \\
(0.06)\end{array}$ & $\begin{array}{l}-0.03 \\
(0.06)\end{array}$ & $\begin{array}{l}-0.02 \\
(0.06)\end{array}$ \\
\hline $\begin{array}{l}\text { Household durable goods } \\
\text { (ref: three or more bikes) } \\
\text { One bicycle }\end{array}$ & $\begin{array}{c}-0.05^{*} \\
(0.028)\end{array}$ & $\begin{array}{r}-0.05 \\
(0.029)\end{array}$ & $\begin{array}{r}-0.05 \\
(0.029)\end{array}$ & $\begin{array}{l}-0.05^{*} \\
(0.028)\end{array}$ \\
\hline Two bicycles & $\begin{array}{r}-0.01 \\
(0.018)\end{array}$ & $\begin{array}{l}-0.01 \\
(0.02)\end{array}$ & $\begin{array}{l}-0.02 \\
(0.02)\end{array}$ & $\begin{array}{r}-0.01 \\
(0.018)\end{array}$ \\
\hline Motorbike or car & $\begin{array}{l}-0.07^{* * *} \\
(0.02)\end{array}$ & $\begin{array}{l}-0.07^{* * *} \\
(0.02)\end{array}$ & $\begin{array}{l}-0.07^{* * *} \\
(0.02)\end{array}$ & $\begin{array}{l}-0.07^{* * *} \\
(0.02)\end{array}$ \\
\hline $\begin{array}{l}\text { Value of hh fixed productive assets } \\
\text { Draught animals, farm tools, } \\
\text { machinery and equipment }\end{array}$ & $\begin{array}{l}\text { sum } \\
-8.3 \mathrm{E}-6^{* * *} \\
(2.6 \mathrm{E}-6)\end{array}$ & item & item & item \\
\hline Draught animals & & $\begin{array}{l}-6.7 \mathrm{E}-6 \\
(6.6 \mathrm{E}-6)\end{array}$ & & \\
\hline $\begin{array}{l}\text { Large and medium sized farm } \\
\text { tools }\end{array}$ & & & $\begin{array}{l}-6.5 \mathrm{E}-5^{* * *} \\
(2.2 \mathrm{E}-5)\end{array}$ & \\
\hline Machinery and equipment & & & & $\begin{array}{l}-8.3 \mathrm{E}-6^{* * *} \\
\quad(3 \mathrm{E}-6)\end{array}$ \\
\hline $\begin{array}{l}\chi^{2} \text { test for joint significance } \\
\text { Number of villages : } \\
\text { Number of households : }\end{array}$ & $\begin{array}{r}422.3 \\
(\mathrm{p}-\mathrm{val}=0 \%) \\
862 \\
8005\end{array}$ & $\begin{array}{r}414.9 \\
(\mathrm{p}-\mathrm{val}=0 \%) \\
862 \\
8005\end{array}$ & $\begin{array}{r}442.1 \\
(\mathrm{p}-\mathrm{val}=0 \%) \\
862 \\
8005\end{array}$ & $\begin{array}{r}421.3 \\
(\mathrm{p}-\mathrm{val}=0 \%) \\
862 \\
8005\end{array}$ \\
\hline
\end{tabular}


Table 5: Dependent variable: Ratio of migration duration to total working time (3)

\begin{tabular}{|c|c|c|}
\hline \multirow[b]{3}{*}{ Variables } & \multicolumn{2}{|c|}{ ICLS Regressions } \\
\hline & ICLS (9) & ICLS (10) \\
\hline & $\begin{array}{c}\text { Coefficient } \\
\text { (Std. Err.) }\end{array}$ & $\begin{array}{l}\text { Coefficient } \\
\text { (Std. Err.) }\end{array}$ \\
\hline Total area of land & $\begin{array}{l}-0.002^{*} \\
(0.001)\end{array}$ & $\begin{array}{l}-0.003^{* * *} \\
(0.0012)\end{array}$ \\
\hline Share of grain ration land & $\begin{array}{r}-0.04 \\
(0.038)\end{array}$ & $\begin{array}{r}-0.04 \\
(0.039)\end{array}$ \\
\hline $\begin{array}{l}\text { Flexible land retained in } 2002 \\
\times \text { Share of grain ration land }\end{array}$ & $\begin{array}{l}\mathbf{0 . 1 9 9}^{* * *} \\
(0.072)\end{array}$ & $\begin{array}{l}\mathbf{0 . 1 9}^{* *} \\
(0.074)\end{array}$ \\
\hline Share of dependent members & $\begin{array}{l}-0.24^{* * *} \\
(0.03)\end{array}$ & $\begin{array}{l}-0.23^{* * *} \\
(0.029)\end{array}$ \\
\hline Years of education of hh head & $\begin{array}{l}-0.006^{* *} \\
(0.0023)\end{array}$ & $\begin{array}{l}-0.005^{* *} \\
(0.0023)\end{array}$ \\
\hline Hh mean age & $\begin{array}{l}-0.03^{* * *} \\
(0.005)\end{array}$ & $\begin{array}{l}-0.03^{* * *} \\
(0.005)\end{array}$ \\
\hline Hh mean age squared & $\begin{array}{l}0.00013^{* * *} \\
(0.00006)\end{array}$ & $\begin{array}{l}0.0002^{* * *} \\
(0.00006)\end{array}$ \\
\hline Hh mean number of men & $\begin{array}{l}0.009 \\
(0.03)\end{array}$ & $\begin{array}{l}-0.02 \\
(0.03)\end{array}$ \\
\hline Ethnic minority & $\begin{array}{l}-0.04 \\
(0.06)\end{array}$ & $\begin{array}{l}-0.02 \\
(0.06)\end{array}$ \\
\hline $\begin{array}{l}\text { Household durable goods } \\
\text { (ref: three or more bikes) } \\
\text { One bicycle }\end{array}$ & $\begin{array}{l}-0.05^{* *} \\
(0.028)\end{array}$ & $\begin{array}{l}-0.05^{* *} \\
(0.028)\end{array}$ \\
\hline Two bicycles & $\begin{array}{r}-0.02 \\
(0.018)\end{array}$ & $\begin{array}{r}-0.02 \\
(0.018)\end{array}$ \\
\hline Motorbike or car & $\begin{array}{l}-0.06^{* * *} \\
(0.02)\end{array}$ & $\begin{array}{l}-0.07^{* * *} \\
(0.02)\end{array}$ \\
\hline $\begin{array}{l}\text { Value of hh fixed productive assets } \\
\text { Draught animals, farm tools, } \\
\text { machinery and equipment }\end{array}$ & $\begin{array}{c}y e s \\
-5.9 \mathrm{E}-6^{* *} \\
(2.4 \mathrm{E}-6)\end{array}$ & no \\
\hline Estimated value of self-owned house & $\begin{array}{l}8.3 \mathrm{E}-7^{* *} \\
(3.6 \mathrm{E}-7)\end{array}$ & \\
\hline $\begin{array}{l}\text { Social status variable } \\
\text { Hh head belongs to CCP }\end{array}$ & no & $\begin{array}{r}y e s \\
0.007 \\
(0.015)\end{array}$ \\
\hline $\begin{array}{l}\chi^{2} \text { test for joint significance } \\
\text { Number of villages : } \\
\text { Number of households : }\end{array}$ & $\begin{array}{r}433.9 \\
(\mathrm{p}-\mathrm{val}=0 \%) \\
862 \\
8005\end{array}$ & $\begin{array}{r}416.8 \\
(\mathrm{p}-\mathrm{val}=0 \%) \\
862 \\
8005\end{array}$ \\
\hline
\end{tabular}

Significance levels: $\quad * 10 \% \quad * * 5 \% \quad * * * 1 \%$ 
Table 6: Dependent variable: Ratio of local off farm work to total working time

\begin{tabular}{|c|c|c|c|}
\hline \multirow[b]{3}{*}{ Variables } & \multicolumn{3}{|c|}{ ICLS Regressions } \\
\hline & ICLS (11) & ICLS (12) & ICLS (13) \\
\hline & $\begin{array}{l}\text { Coefficient } \\
\text { (Std. Err.) }\end{array}$ & $\begin{array}{l}\text { Coefficient } \\
\text { (Std. Err.) }\end{array}$ & $\begin{array}{l}\text { Coefficient } \\
\text { (Std. Err.) }\end{array}$ \\
\hline Total area of land & $\begin{array}{l}-0.007^{* * *} \\
(0.0015)\end{array}$ & $\begin{array}{l}-0.007^{* * *} \\
(0.0014)\end{array}$ & $\begin{array}{l}-0.007^{* * *} \\
(0.0016)\end{array}$ \\
\hline Share of grain ration land & $\begin{array}{r}-0.04 \\
(0.033)\end{array}$ & $\begin{array}{r}-0.04 \\
(0.033)\end{array}$ & $\begin{array}{r}-0.04 \\
(0.032)\end{array}$ \\
\hline $\begin{array}{l}\text { Flexible land retained in } 2002 \\
\times \text { Share of grain ration land }\end{array}$ & $\begin{array}{l}0.075 \\
(0.05)\end{array}$ & $\begin{array}{r}0.075 \\
(0.049)\end{array}$ & $\begin{array}{r}0.075 \\
(0.049)\end{array}$ \\
\hline Share of dependent members & $\begin{array}{l}0.05^{* * *} \\
(0.021)\end{array}$ & $\begin{array}{l}0.05^{* * *} \\
(0.022)\end{array}$ & $\begin{array}{l}0.07^{* * *} \\
(0.021)\end{array}$ \\
\hline Years of education of hh head & $\begin{array}{l}0.016^{* * *} \\
(0.0018)\end{array}$ & $\begin{array}{l}0.017^{* * *} \\
(0.0018)\end{array}$ & $\begin{array}{l}0.014^{* * *} \\
(0.0018)\end{array}$ \\
\hline Hh mean age & $\begin{array}{l}0.015^{* * *} \\
(0.0035)\end{array}$ & $\begin{array}{l}0.016^{* * *} \\
(0.0036)\end{array}$ & $\begin{array}{l}0.015^{* * *} \\
(0.0035)\end{array}$ \\
\hline Hh mean age squared & $\begin{array}{l}-0.0002^{* * *} \\
(0.00004)\end{array}$ & $\begin{array}{l}-0.0002^{* * *} \\
(0.00004)\end{array}$ & $\begin{array}{l}-0.0002^{* * *} \\
(0.00004)\end{array}$ \\
\hline Hh mean number of men & $\begin{array}{l}-0.004 \\
(0.024)\end{array}$ & $\begin{array}{r}-0.0008 \\
(0.025)\end{array}$ & $\begin{array}{l}-0.005 \\
(0.024)\end{array}$ \\
\hline Ethnic minority & $\begin{array}{l}-0.02 \\
(0.04)\end{array}$ & $\begin{array}{l}-0.02 \\
(0.04)\end{array}$ & $\begin{array}{l}-0.02 \\
(0.04)\end{array}$ \\
\hline $\begin{array}{l}\text { Household durable goods } \\
\text { (ref: three or more bikes) }\end{array}$ & yes & no & yes \\
\hline One bicycle & $\begin{array}{r}-0.03 \\
(0.021)\end{array}$ & & $\begin{array}{r}-0.03 \\
(0.021)\end{array}$ \\
\hline Two bicycles & $\begin{array}{l}-0.04^{* * *} \\
(0.012)\end{array}$ & & $\begin{array}{l}-0.03^{* * *} \\
(0.012)\end{array}$ \\
\hline Motorbike or car & $\begin{array}{l}0.07^{* * *} \\
(0.011)\end{array}$ & & $\begin{array}{l}0.07^{* * *} \\
(0.011)\end{array}$ \\
\hline $\begin{array}{l}\text { Social status variable } \\
\text { Hh head belongs to the CCP }\end{array}$ & no & no & $\begin{array}{c}\text { yes } \\
0.08^{* * *} \\
(0.01)\end{array}$ \\
\hline $\begin{array}{l}\chi^{2} \text { test for joint significance } \\
\text { Number of villages : } \\
\text { Number of households : }\end{array}$ & $\begin{array}{r}229.3 \\
(\mathrm{p}-\mathrm{val}=0 \%) \\
862 \\
8005\end{array}$ & $\begin{array}{r}169.6 \\
(\text { p-val }=0 \%) \\
862 \\
8005\end{array}$ & $\begin{array}{r}295.6 \\
(\mathrm{p}-\mathrm{val}=0 \%) \\
862 \\
8005\end{array}$ \\
\hline
\end{tabular}

Significance levels: $\quad * 10 \% \quad * * 5 \% \quad * * * 1 \%$ 
Table 7: Descriptive statistics for the main variables of interest.

\begin{tabular}{|c|c|c|c|c|c|c|}
\hline Households & \multicolumn{2}{|c|}{ All } & \multicolumn{2}{|c|}{$\begin{array}{c}\text { With } \\
\text { migrant worker(s) }\end{array}$} & \multicolumn{2}{|c|}{$\begin{array}{c}\text { Without } \\
\text { migrant worker }(\mathrm{s})\end{array}$} \\
\hline Variables & Mean & St. Dev. & Mean & St. Dev. & Mean & St. Dev. \\
\hline $\begin{array}{l}\text { Share of hh working time de- } \\
\text { voted to: } \\
\text { Migration }\end{array}$ & 0.1 & 0.193 & 0.36 & 0.195 & 0 & 0 \\
\hline Local off-farm work & 0.22 & 0.286 & 0.07 & 0.139 & 0.28 & 0.308 \\
\hline Total area of land & 9.28 & 9.781 & 8.3 & 8.45 & 9.68 & 10.249 \\
\hline Share of grain ration land & 0.39 & 0.377 & 0.42 & 0.373 & 0.37 & 0.378 \\
\hline Years of education of hh head & 7.16 & 2.608 & 6.9 & 2.603 & 7.27 & 2.603 \\
\hline Share of dependent members & 0.31 & 0.23 & 0.26 & 0.214 & 0.33 & 0.234 \\
\hline Hh mean number of men & 0.57 & 0.197 & 0.55 & 0.18 & 0.57 & 0.203 \\
\hline Hh mean age & 39.07 & 8.112 & 36.86 & 6.051 & 39.97 & 8.655 \\
\hline Hh mean age squared & 1684.9 & 713.095 & 1528.72 & 505.32 & 1748.6 & 773.181 \\
\hline Ethnic minority & 0.12 & & 0.1 & & 0.13 & \\
\hline $\begin{array}{l}\text { Hh durable goods - Proportion } \\
\text { of hhs having: } \\
\text { One bicycle }\end{array}$ & 0.18 & & 0.21 & & 0.16 & \\
\hline Two bicycles & 0.28 & & 0.31 & & 0.27 & \\
\hline Three or more bicycles & 0.26 & & 0.28 & & 0.27 & \\
\hline Motorbike or car & 0.28 & & 0.2 & & 0.3 & \\
\hline $\begin{array}{l}\text { Value of hh fixed productive as- } \\
\text { sets (Yuan): }\end{array}$ & & & & & & \\
\hline Draught animals & 727 & 1825 & 568 & 1160 & 797 & 2030 \\
\hline Farm tools & 250 & 1034 & 227 & 368 & 259 & 1203 \\
\hline Machinery and equipment & 1087 & 3210 & 689 & 1848 & 1248 & 3607 \\
\hline Sum of three previous items & 2063 & 3987 & 1484 & 2304 & 2298 & 4472 \\
\hline Estimated value of house & 23485 & 28591 & 21435 & 22827 & 24316 & 30584 \\
\hline Hh head belongs to CCP & 0.17 & & 0.15 & & 0.18 & \\
\hline Number of households & & 005 & & 19 & & 686 \\
\hline
\end{tabular}

All samples are restricted to households having some land and having at least one working member. 